\title{
Research on the Training Mode of Innovation Undertaking in Local Universities Against the Background of "Internet Plus"
}

\author{
Dongxing Jing \\ College of Foreign Language \\ Pingdingshan University \\ Pingdingshan, China
}

\begin{abstract}
At present, the employment pressure of college students is increasing with the expansion of college graduates. Against the background of "Mass entrepreneurship and innovation" and the development of information technology, "Internet plus" provides a variety of employment opportunities. Many local colleges and universities have successively set up undergraduate innovative undertaking education courses to alleviate the employment pressure, but the courses have many problems including fuzzy location of education, singleness of personal training mode, defectiveness of scientificity, weak awareness of teachers and students as well as weakness of faculty. As a result, innovation and entrepreneurship education doesn't reach a desired effect. Society and school should take advantage of "Internet plus" to improve the above problems, so as to realize the purpose of cultivating innovative and entrepreneurial talents.
\end{abstract}

Keywords-Internet plus; innovative undertaking; talent cultivation

\section{INTRODUCTION}

At present, the employment pressure of college students is increasing because of the number of graduates. Many local universities successively have successively set up undergraduate innovative undertaking education courses to alleviate the employment pressure, so as to realize highquality and rapid employment of students and thus improve the employment quality and employment rate. Since Premier Li Keqiang first proposed the concept of "Internet +", "Internet + " has played an increasingly important role in economic and social development, especially in the integration and optimization of social resources allocation. The full inclusion of Internet innovations in the economic and social fields will significantly enhance the productivity and innovation capability of the whole society, which provides a large number of opportunities for innovation and entrepreneurship. Therefore, in the context of "Internet + ", the research on the cultivation mode of innovative and entrepreneurial talents for college students is very necessary for colleges and universities, and of great significance for effectively improving the innovation and entrepreneurship education reform for college students.

\section{CURRENT SITUATION OF INNOVATION AND ENTREPRENEURSHIP EDUCATION IN LOCAL COLLEGES IN CHINA}

\section{A. Single Mode of Education}

At present, most local colleges in China are constantly looking for the best innovative and entrepreneurial talent training mode. It also is the choice of them to combine the characteristics of local economic development and their college. Now, there are three frequently-used modes of talent cultivation, which are the teaching of specialized courses, the focus of activities and competitions, and the establishment of innovative and pioneering parks. However, most local colleges in China start relatively late in carrying out innovation and entrepreneurship education. On the one hand, they do not have a deep understanding of the connotation of innovation and entrepreneurship education, and they lack the corresponding professional and technical experts reserve and hardware support. On the other hand, colleges have limited efforts in curriculum construction and students are lack of applicable professional textbooks and scientific curriculum evaluation and assessment methods, making students have less motivated in the learning process, which leads to unsatisfactory effect of training.

\section{B. Vague Educational Orientation}

Most colleges have set up innovative entrepreneurship education, but due to the insufficient understanding of it, colleges still put the employment and professional knowledge closely tying together and put the professional education and skills as the key point in teaching, which leads to the main focus of the teaching work's is not inclined to the course but concentrated in professional courses and knowledge, so the teaching effect is too little effect. Some colleges stick to traditional thought and they do not implement construction of applied undergraduate thought, which still adhere to the training mode of elite education, spending a lot of time, energy and education resource on key disciplines and key talent. But in the innovation and entrepreneurship education of students, their input is often 
not enough, so the students' innovation ability can't improve effectively.

\section{Formalized Teaching Process}

Many local colleges and universities have set up courses on innovation and entrepreneurship education for a relatively short period of time. At present, they are still in the stage of "crossing the river by feeling for stones" and have not yet found out a complete and scientific teaching model. In this way, teachers have great freedom in the process of teaching, and the effect of teaching often depends on the individual ability of teachers. In the teaching of innovation and entrepreneurship education, most teachers prefer theoretical courses, and the proportion of setting theoretical courses is much higher than that of activity courses and practical courses, which is not conducive to cultivating students' innovative thinking. Some teachers tend to focus on the knowledge of employment, such as employment policies and relevant laws and regulations, recruitment skills and experience. Although the knowledge of employment can help and guide college graduates, it has little effect on the improvement of students' innovation ability.

\section{THE UPDATE OF THE TRAINING MODE OF} INNOVATIVE AND ENTREPRENEURIAL TALENTS FOR COLlEge Students AgAinst THE BACKGROUND OF "INTERNET PLUS"

\section{A. Creating an Atmosphere of Innovation and Entrepreneurship}

Innovation and entrepreneurship ability is very important for the career of college students. The society, especially the college, should carry out multi-channel and multi-coverage publicity of this concept. A good social environment can enable students to establish the consciousness of innovation and entrepreneurship, so that more students can join the team of innovation and entrepreneurship. Since the country put forward the concept of "Internet + ", entrepreneurship and innovation and "Internet + " have a closely connection, under the background of "Internet + ", teachers should create innovative entrepreneurial opportunities to target to the classroom, make students have more clear understanding of the current situation of innovative undertaking and encourage students to try to develop into an inter-disciplinary talent.

\section{B. Making Clear Plan}

Now many local colleges and universities is not very clear of innovative entrepreneurial talent training plan and goal, this makes no direction in the process of the cultivation of the talent, so the college must organize expert team to carry out the revision of the talent training scheme, for the development of social economy, the present situation of the students' innovative ability in detail investigation, after fully demonstrated to develop a clear and scientific talent training scheme. For example: college should combine its own characteristics of local economic development, to evaluate students' innovative entrepreneurial awareness ahead of time, around the "cultivating talents and how to cultivate talents", the core issue of clear overall mission of training students' innovative undertaking, stage detailed learning objectives, in order to achieve the target in the training process.

\section{Strengthening School-enterprise Collaboration and Education}

On the one hand, schools should fully concentrate social resources, give play to the role of relevant functional departments, strengthen the contact with relevant enterprises, coordinate the interests of all aspects between schools and enterprises in the process of cooperation, and fully mobilize the enthusiasm of enterprises to participate. On the other hand, for students in school, when they have accepted the study of professional theory courses and passed the examination, they could directly participate in practical activities in the production line of enterprises, so that students can apply the theories they have learned in a more realistic environment and fully apply the theoretical knowledge to the practice process. Students will improve their practical ability and innovation ability substantially through the acute experience of combat environment and the process of "discovering and solving problems".

\section{Integrating the Course Content with Innovation and Entrepreneurship Content}

In the current information technology era, the emergence of the Internet has broken the traditional education model. With the breaking of the boundaries between education space and time, students can participate in the curriculum and receive education more freely. The school should keep up with the development of The Times and find out the development status of innovation and entrepreneurship. The university should give full play to the characteristics of Internet information education technology that is easily accepted by college students, which is more conducive to its diversified education. Through the reform and exploration of curriculum, the school has established a three-dimensional education model, namely the trinity education of network, classroom and practice, integrating the curriculum content with innovation and entrepreneurship content, so as to effectively improve the innovation and entrepreneurship ability of students, to improve the employment quality of students and alleviate the employment pressure.

\section{E. Improving Teachers' Innovative and Entrepreneurial Ability}

The improvement of teaching quality cannot be separated from teachers' ability and effort. Building a team of teachers with innovative entrepreneurial ability and experience plays a very important role in the transmission of entrepreneurial knowledge and entrepreneurial spirit. On the one hand, schools should often carry out entrepreneurship, innovation and career planning training for professional teachers, requiring teachers to come to the front-line production and life of enterprises to sum up the experience of enterprise production management; Schools should encourage teachers to participate in relevant Internet conferences to keep abreast of the latest development of the Internet; Schools should provide policy support for capable and thoughtful teachers to 
carry out innovation and entrepreneurship activities, and to incorporate the experience accumulated in practice into relevant courses. On the other hand, schools should provide policies to strengthen the innovative and entrepreneurial faculty. Schools can hire industry mentors or managers of Internet-related enterprises to participate in the activities of students' innovation and entrepreneurship education and training. This is conducive to full-time teachers and industry mentors to give full play to their respective advantages, to provide guarantee for innovation and entrepreneurship education.

\section{CONCLUSION}

With the emergence of information technology, the development of the "Internet + " has brought a great deal of development opportunities to today's social economy, under this background, it has greatly promoted to the college students' innovation and entrepreneurship education. The innovation and start-up education in local colleges and universities should follow the national development strategy, put the "Internet + " plan of action into practice, find the position of the qualified personnel, actively reform the training mode, and establish an excellent team of teachers, so as to better cultivate the innovation and entrepreneurship abilities of college students and improve the employment quality and the employment rate of the graduates.

\section{REFERENCES}

[1] Chen Shensheng, The Innovation and entrepreneurship training and school enterprise cooperation system under the background of "Internet +", Journal of Hebei Youth Management Cadre College, 2018, 30(4): 60-63.

[2] Luli, Research on talent training mode of innovation and entrepreneurship education in Universities under the background of "Internet +". Primary and secondary school audio-visual education.2017, 5: 16-19.

[3] Liu Xiaodi. The construction of a new mode of College Students' innovation and entrepreneurship education in the era of "Internet +", Higher Education Journal, 2017 (3): 7-8.

[4] Wei Jia. Research on personnel training mode of school enterprise cooperation in Applied Undergraduate Universities under the background of "Internet +", Journal of Jilin Institute of Education, 2018 (34): 54-57. 